УДК 316

БАРАШ Раиса Эдуардовна - кандидат политических наук, ведущий научный сотрудник Института социологии ФНИСЦ РАН (117218, Россия, г. Москва, ул. Кржижановского, 24/35, кopn. 5; raisabarash@gmail.com)

\title{
НЕМАТЕРИАЛЬНЫЕ ФАКТОРЫ ПРОТЕСТНОЙ КОММУНИКАЦИИ И КОНСОЛИДАЦИИ: РОССИЙСКИЙ КОНТЕКСТ Часть 2
}

\begin{abstract}
Аннотация. Обращаясь к исследованию генезиса протестной консолидации под влиянием нематериальных факторов, автор задается вопросом о влиянии повсеместного расширения новых медиа и цифровой коммуникации на протестную активность последних лет. Опираясь на социологические данные, автор резюмирует, что в современной России широкое распространение Интернета и доступа к социальным сетям не консолидирует серьезный протестный потенциал и даже не политизирует digitalаудиторию. Однако свойственная электронным медиа традиция свободной коммуникации и дискуссионного общения формируют у регулярных российских пользователей digital-media запрос на возможности прямого выражения собственных взглядов, информационную открытость и общества, и власти, что оказывает влияние на динамику общественного мнения о ситуации в стране, способствует идейной консолидации многих социально активных граждан.

Ключевые слова: протест, коммуникация, активизм, Интернет, социальные сети, консолидация
\end{abstract}

\section{Консолидационный потенциал протестной коммуникации в электронных медиа: российский контекст}

В 2019 и 2020 гг. в нескольких регионах России состоялись протестные выступления. И если по формальным основаниям сложно было уравнять «мусорные» протесты против проекта строительства полигона для утилизации отходов в Архангельской обл., выступления против решения властей Екатеринбурга и Свердловской обл. о строительстве храма на территории популярного у горожан сквера, арест по подложному обвинению московского журналиста Ивана Голунова, то с коммуникативной точки зрения протестная консолидация во всех случаях происходила из неприятия гражданами своего отстранения от принятия социально и политически значимых решений [Бараш 2014], «когда политическая система оказывается закупоренной... [и] перестала быть пригодной для канализации самого разнообразного социального и политического недовольства» 1 . Т. Становая связывает жесткую реакцию властей на московские протесты лета 2019 г. с коммуникативной закрытостью властей для граждан, поскольку «власть не видит субъекта для диалога, а значит, не может быть и никаких уступок» ${ }^{2}$. А. Колесников интерпретировал протесты жителей Хабаровского края против ареста избранного губернатора С. Фургала летом 2020 г. как «результат передавливания, итог сверхмобилизации... бумеранг после принуждения к голосованию» по поправкам к Конституции летом 2020 г., отмечая, что главным мотивом недовольства жителей региона была не уверен-

\footnotetext{
1 Гостев А.С. 2019. Рецепт революции. - Радио Свобода. Доступ: www.svoboda.org/a/30236548.html (проверено 03.03.2021).

2 Становая Т.А. 2019. Бенефициары лета. Как властные группы наращивают портфель к 2024 году. Московский центр Карнеги. Доступ: carnegie.ru/commentary/80193 (проверено 03.03.2021).
} 
ность в невиновности избранного чиновника, но «протест обманутых надежд», негодование оттого, что «у людей крадут выбор» 1 .

Несмотря на отдаленность региона, за ситуацией в Хабаровском крае внимательно следили граждане по всей стране. Многие россияне выражали солидарность с жителями Камчатки, протестовавшими против утаивания местными властями причин загрязнения океанического побережья полуострова. Пристальный интерес граждан к протестным выступлениям в отдаленных регионах страны стал возможен в определяющей степени благодаря местным жителям и блогерам, растиражировавшим в социальных сетях, в Telegram- и YouTube-каналах информацию о ситуации в своих регионах.

Протестные выступления 2011-2012 гг. в России, сложившиеся в коммуникацию и солидарные действия представителей самых разных социально-экономических и демографических групп, носителей зачастую противоречивых ценностей и политических взглядов, несомненно, стали возможны в т.ч. и благодаря обращению «недовольных» к электронным медиа. Но после обвинительных приговоров и реальных тюремных сроков для участников «Болотного» и «Московского» дел, дела «Сети», а также многочисленных штрафов в отношении организаторов и участников митингов многие критично настроенные граждане выбрали для себя личную свободу, отказавшись от участия в протестных мероприятиях.

Кроме того, после 2012 г. было серьезно ужесточено законодательство о митингах, расширена система санкций за его неисполнение, вплоть до введения уголовной ответственности для рядовых участников несанкционированных собраний и манифестаций, что также заставило многих недовольных отказаться от активизма. Заметно снизил градус виртуальной протестной коммуникации и серьезно ограничил возможность протестных выступлений целый комплекс законодательных инициатив, принятых после 2012 г. Распространение ограничений антиэкстремистского законодательства (принятие ряда поправок к УК РФ) на Интернет и социальные сети предоставило правоохранительным органам возможность уголовного и административного преследования за «протестный контент» (посты, лайки и репосты).

Несмотря на широкие ограничения возможностей виртуального самовыражения, Интернет в России остается неотъемлемой частью повседневности, важным средством коммуникации и гражданского активизма, тем более что, согласно многочисленным результатам исследования медийного пространства, интернет-вовлеченность россиян неуклонно растет. По данным Всероссийского омнибуса $G f K$, в начале 2019 г. число интернет-пользователей в России старше 16 лет увеличилось на 3 млн чел. и составило 90 млн, достигнув показателя в $75 \%$ взрослого населения страны ${ }^{2}$. Красноречивой приметой превращения электронных медиа в полноценный механизм коммуникации стало организованное ЦИКом РФ летом 2020 г. онлайн-голосование для жителей Москвы и Нижегородской обл. по поправкам к Конституции РФ.

Исследование ФНИСЦ РАН 2020 г. ${ }^{3}$ подтвердило постоянно возрастающий масштаб интернет-вовлеченности россиян. За последние 10 лет доля регуляр-

1 Колесников А.В. 2020. Хабаровская инфекция: почему дальневосточные протесты могут распространяться со скоростью ковида. - Forbes.ru. Доступ: https://www.forbes. ru/obshchestvo/405355-habarovskaya-infekciya-pochemu-dalnevostochnye-protesty-mogutrasprostranyatsya (проверено 03.03.2021).

2 Исследование GfK: Проникновение Интернета в России. - Gfk.com. Доступ: https://www. gfk.com/ru/press/issledovanie-gfk-proniknovenie-interneta-v-rossii (проверено 03.03.2021).

3 Статья основывается на данных исследования Федерального научно-исследовательского социологического центра Российской академии наук, проведенного в 2020 г. в рамках реализации проекта Российского научного фонда (проект № 20-18-00505). 
ных пользователей Интернета (пользуются не реже 1 раза в неделю) выросла в 2,5 раза - с 34\% в 2010 г. до 82\% 2020 г. Среди них подавляющее большинство (64\%) пользуются Интернетом ежедневно. Доля тех, кто вообще не пользуется Интернетом, за последние 5 лет сократилась с 24\% до 16\%. Схожая ситуация и с массовым вовлечением россиян в социальные сети: 68\% граждан вовлечены в социальные сети и регулярно пользуются ими, из них почти половина (48\%) ежедневно. За 5 лет доля регулярных пользователей социальных сетей выросла на $20 \%$ - с $47 \%$ в 2015 г. до $68 \% 2020$ г.

Однако расширение виртуального пространства не имеет результатом рост политической коммуникации. Лишь 2-3\% активных пользователей Интернета и соцсетей обращаются к последним для общения с политическими единомышленниками, не более $1 \%$ - для участия в организации и проведении политических и гражданских акций. Активная вовлеченность в электронные медиа и регулярный доступ к новостному контенту социальных сетей и Интернета в современной России не выливается в резко критические оценки актуальной повестки. Респонденты, получающие информацию из социальных сетей и Интернета, не отличаются радикальностью оценок ситуации в России от своих сограждан, черпающих информацию о мире преимущественно из телевизионных передач.

При этом открытая информационная среда, свободный доступ к информации и возможности личного самовыражения и свободного общения критически важны для активной аудитории электронных медиа. 74\% аудитории и интернетизданий, и соцсетей оценили возможность доступа к информации и свободного общения в Интернете как важную и очень важную для себя лично. Среди ТВ-аудитории запрос на открытую информационную среду также велик (52\%), но выражен заметно меньше. О высокой важности для себя информационной открытости телезрители заявляли на 22\% реже, чем интернет-пользователи.

Еще резче эта разница в актуальном запросе на информационную открытость проявляется среди тех, кто регулярно пользуется Интернетом (70\%) и социальными сетями $(74 \%)$ и не включен в виртуальные медиа $(27-31 \%)$. Запрос на свободу слова и открытые СМИ в российском обществе в целом высок - об их важности заявили $83 \%$ граждан. Но чаще других о важности свободной коммуникации и открытого доступа к информации говорили активные участники Интернета и социальных сетей (87\% против $72 \%$ среди граждан, не включенных в электронные медиа).

Большинство опрошенных россиян (66\%) считают важным для современного российского общества право граждан на мирный протест как способ репрезентации собственных прав и проблем, в первую очередь власти. Среди регулярных пользователей цифровых медиа запрос на государственно гарантированное право мирного протеста на $13 \%$ выше, чем среди россиян, не пользующихся Интернетом и социальными сетями (68-69\% против 55-57\%).

Запрос на информационную открытость аудитория новых медиа распространяет также и на власть. Среди необходимых атрибутов власти, доступных для граждан, наиболее значимые, по мнению участников опроса, относятся не к прямой физической близости управленческих институтов, но к их информационной открытости и коммуникативной доступности. Это доступность (открытость) информации о деятельности органов власти (назвали $49 \%$ респондентов), возможность личного общения с представителями органов власти (40\%), открытость информации о биографиях представителей власти, об их доходах и наличии недвижимости (32\%), готовность представителей власти дискутировать с представителями оппозиции и гражданского общества (29\%).

Если актуальность запроса на открытость информации о деятельности орга- 
нов власти и биографиях представителей власти, об их доходах и недвижимости примерно одинакова для граждан и включенных в электронные сети, и не участвующих в них, то совсем иная ситуация складывается с ожиданиями личной информационной доступности и коммуникативной открытости власти для рядовых граждан. Запрос на прямое общение представителей власти с гражданами заметно выше среди активных участников виртуальной коммуникации, чем среди прочих граждан.

Возможность личного общения с представителями органов власти кажется современным россиянам второй по значимости характеристикой доступности власти (40\%). Среди респондентов, активно включенных в виртуальную коммуникацию, запрос на такую персональную открытость на 8-10\% выше, чем среди граждан, не пользующихся ресурсами Сети (42\% против 32-35\%). Такая же ситуация и с запросом на открытую дискуссию представителей власти с представителями оппозиции и гражданского общества. $29 \%$ всех респондентов назвали в качестве атрибута доступности власти готовность представителей власти к такой дискуссии. Но среди активных пользователей Интернета и соцсетей такой запрос к власти выражен гораздо серьезнее - у трети (32\%) против 19-21\% респондентов, не включенных в электронную коммуникацию. Заметно выше, чем среди телеаудитории (26\%), запрос на коммуникативную открытость власти, готовность к дискуссии с гражданским обществом и оппозицией выражен среди аудитории новостных интернет-ресурсов (37\%) и социальных сетей (34\%).

Среди граждан, которые активно пользуются Интернетом и социальными сетями, заметно выше запрос на социальные перемены. Большинство респондентов (60\%), ежедневно пользующихся Интернетом, уверены, что страна нуждается в существенных переменах, нужны новые реформы в экономической и политической жизни страны. Меньшинство (39\%) полагает, что стране нужна стабильность. Установки россиян, не пользующихся Интернетом / соцсетями, полностью противоположны: большинство (63\%) - за стабильность, меньшинство $(36 \%)$ - за перемены.

Но может ли актуальный запрос на перемены, в первую очередь среди «коммуникативно продвинутых» россиян, их высокий «модернистский потенциал» трансформироваться в конкретные действия, направленные на изменение сложившейся ситуации? Результаты опроса свидетельствуют о том, что регулярные пользователи Интернета и социальных сетей действительно гораздо более активны, решительны и изобретательны в сложных ситуациях, в частности при значительном ухудшении своей жизни. Среди активных пользователей Интернета более чем в 2 раза выше доля респондентов, готовых к поиску новых источников заработка (37 против 14\%), тогда как более трети (37\%) россиян, не участвующих в электронных медиа, заявили, что предпринимать ничего не будут. Но консолидационный потенциал виртуальных сетей как фактор складывания коллективной реакции крайне низок. Лишь 11-12\% регулярных пользователей Интернета и социальных сетей заявили о готовности принять участие в митингах, демонстрациях, голодовках в случае ухудшения своего положения или положения своей семьи. Это в 2 раза больше, чем среди граждан, не включенных в виртуальные сети. Но этого явно не достаточно для того, чтобы приписывать революционный потенциал интернет-коммуникации. Еще 4\% активных пользователей Интернета и социальных сетей заявили о готовности отстаивать свои интересы через профсоюзные организации, 3\% - о намерении вступить для защиты своих интересов в политическую партию.

Сегодня в митингах и демонстрациях, направленных на защиту экономических и социальных прав, готовы участвовать не более $1 / 4$ граждан, а в акциях 
защиты демократических прав и свобод - еще меньше, 18\%. В условиях серьезного запроса граждан на перемены и невысокого уровня доверия власти и скепсиса в отношении проводимой ею политики уровень протестной консолидации (18-25\%) крайне низок. Но с учетом ужесточения законодательства о митингах, а также ряда громких разбирательств в отношении политических активистов это объяснимо.

При этом номинально широкий доступ в Интернет действительно коррелирует с большей «протестной готовностью» digital-аудитории. Почти треть (28-30\%) активных пользователей социальных сетей и Интернета готовы принять участие в протестных выступлениях по социальным или экономическим вопросам. Среди россиян, не включенных в виртуальные сети, этот показатель заметно ниже - 18-19\%. Среди активных пользователей электронных медиа декларируемый уровень готовности активно защищать основные демократические права и свободы: свободу слова, право на самовыражение, свободу собраний также несколько выше. Более 1/4 активной аудитории Интернета и социальных сетей (21-24\%) готовы принять участие в массовых выступлениях в защиту демократических прав и свобод. Доля регулярных телезрителей, готовых участвовать в подобных выступлениях, более чем на $10 \%$ ниже (16\%). Если среди представителей активной телевизионной аудитории в той или иной степени возможность участия в митингах в защиту демократических прав для себя исключают 76\%, то представители аудитории электронных медиа такую возможность для себя исключают на $12 \%$ реже (64\%).

На первый взгляд может показаться, что интернет-коммуникация способна консолидировать серьезный протестный потенциал. Однако значительного влияния на гражданскую самоорганизацию новые медиа в современной России не оказывают. Тематика интернет-коммуникации предельно разнообразна и, главное, редко ориентирована на практический результат или долгосрочный план социально-политического реформирования государственной политики. Среди активных пользователей социальных сетей и Интернета доля мотивированных активистов очень мала. Лишь 7\% из них принимали участие в выборных кампаниях в качестве наблюдателя, агитатора, сборщика подписей и т.п. в течение последнего года - полутора лет; еще 5\% участвовали в благотворительных и волонтерских движениях; 4\% - в общественном самоуправлении по месту жительства; 3\% - в деятельности профсоюзной организации. Лишь $3 \%$ респондентов, активно вовлеченных в электронную коммуникацию, в течение последних полутора лет принимали участие в общественно-политических акциях (митинги, демонстрации и т.п.).

Таким образом, появление электронных средств коммуникации значительно упростило регулярное взаимодействие внутри малых групп, упрочило так называемые слабые связи, создав структуру регулярных горизонтальных коммуникаций внутри локальных сообществ. Номинальный же потенциал социальных сетей как механизма политической коммуникации и консолидации очень невысок, политизированная аудитория Интернета и социальных сетей, несмотря на расширяющиеся сети виртуальной коммуникации, не спешит к протестной виртуальной самоорганизации. В значительной степени это производное от сложившихся возможностей политического участия. Однако свойственная электронным медиа традиция свободной коммуникация и дискуссионного общения формирует у регулярных российских digital-пользователей запрос на возможности прямого выражения собственных взглядов, информационную открытость и граждан, и власти, что, несомненно, оказывает влияние на динамику общественного мнения о ситуации в стране, а также способствует консо- 
лидации идей многих социально активных граждан вокруг ценностей коммуникативной открытости и информационной свободы.

Исследование выполнено за счет гранта Российского научного фонда (проект № 20-18-00505) в Федеральном научноисследовательском социологическом центре Российской академии наук.

\title{
Список литературы
}

Бараш Р.Э. 2014. Протестное движение: в поисках нового политического субъекта. - Власть. № 10(22). С. 52-61.

BARASH Raisa Eduardovna, Cand.Sci. (Pol.Sci.), Leading Researcher of the Centre for Complex Social Studies, Institute of Sociology - Branch of the Federal Center of Theoretical and Applied Sociology, Russian Academy of Sciences (bld. 5, 24/35 Krzhizhanovskogo St, Moscow, Russia, 117218; raisabarash@gmail.com)

\section{NON-MATERIAL FACTORS OF THE PROTEST COMMUNICATION AND CONSOLIDATION: THE RUSSIA'S CONTEXT}

\section{Part 2}

\begin{abstract}
The author studies the protest consolidation through the prisms of the non-material factors influence and wonders whether the expanding digital media turns to a revolutionary self-organization mechanism. On the base of sociological data the author concludes that in contemporary Russia the wide spreading of the digital communication does not consolidate a serious protest potential and does not even politicize the digital audience. But the tradition of the open public communication, discussion and chatting in Internet, social networks, etc. creates among regular Russian digital-media users a request for the direct expression of their views, informational openness of both society and the authorities. Such cultural attitudes influence the dynamics of public opinion about the situation in the state and contribute to the ideological consolidation of many socially active citizens.
\end{abstract}

Keywords: protest, communication, activism, Internet, social media, consolidation 